\title{
Diffuse intravascular coagulation in association with myocardial infarction and multiple angiolipomata
}

\author{
G. J. S. RuSTIN \\ M.B., B.S., M.R.C.P. \\ Whittington Hospital, London N19 5NF
}

DifFuse intravascular coagulation has been described in association with many conditions but it has not been reported before in a patient with multiple angiolipomata; myocardial infarction was also a contributory factor in this case.

\section{Case report}

A 60-year-old man was admitted complaining of increasing dyspnoea on exertion with paroxysmal nocturnal dyspnoea for 1 week; he did not have chest pain. During an admission in 1957 for stripping of his varicose veins, one of many subcutaneous lumps that had become more numerous since his teens was biopsied and found to be an angiolipoma. His father and three of his six siblings had similar lumps.

He was very ill, sweating with dyspnoea and an irregular pulse of $200 / \mathrm{min}$. The systolic blood pressure was $70 \mathrm{mmHg}$, the diastolic being unrecordable. $\mathrm{He}$ had congestive cardiac failure with pitting ankle oedema, bilateral basal crepitations and hepatomegaly. Further examination showed many soft, non-tender subcutaneous lumps over his trunk and limbs and also several superficial dilated veins over his back and chest.

Chest X-ray confirmed gross cardiomegaly with pulmonary oedema and an electrocardiogram showed fast atrial fibrillation with left bundle branch block, whereas, 2 years before, his ECG had been normal.

He was treated with digoxin and intravenous and oral doses of frusemide. On the second day he developed bruising over most of his angiolipomata. The bruising became more extensive over the following few days, and the lumps became firm, the dilated vessels appearing to clot. On the fourth day he became jaundiced although by then his heart failure was improving.

Haematological investigations were as shown in Table 1.

The whole blood clot lysis rate was not increased on day 3 although the clot was fragile, suggesting hypofibrinogenaemia. Blood urea was $15.9 \mathrm{mmol} / 1$ $(96 \mathrm{mg} / 100 \mathrm{ml})$ and lactate dehydrogenase was 1613 i.u./l on day 1 ; bilirubin rose to $133 \mu \mathrm{mol} / \mathrm{l}$

Correspondence: Dr G. J. S. Rustin, University College Hospital, Gower Street, London WC1E 6AU.
TABLE 1. Haematological investigations

\begin{tabular}{lrrrrr}
\hline & \multicolumn{5}{c}{ Day } \\
\cline { 2 - 6 } & 2 & 3 & 6 & 9 & 13 \\
\hline $\begin{array}{c}\text { Prothrombin time } \\
\quad(\text { control 13 sec) }\end{array}$ & 63 & 47 & & 15 & \\
$\begin{array}{l}\text { Platelet count }\left(\times 10^{9} / 1\right) \\
\text { Fibrin degradation } \\
\text { products } \\
(<10 \mu \mathrm{g} / \mathrm{ml})\end{array}$ & 111 & & 81 & 110 & 186 \\
$\begin{array}{c}\text { Fibrinogen } \\
(1.5-4.0 \mathrm{~g} / \mathrm{l})\end{array}$ & & 200 & & $50-60$ \\
\hline
\end{tabular}

$(7.8 \mathrm{mg} / 100 \mathrm{ml})$ by day 5 ; haemoglobin remained normal throughout. The falling platelet count, falling fibrinogen and rising fibrin degradation products suggested defibrination, but as he was not overtly bleeding no therapy apart from vitamin $\mathrm{K}$ was given. The bruising and jaundice slowly cleared and when the patient was discharged on day 29 after admission, all blood investigations were normal. Biopsy of firm swelling, taken during convalescence showed haemorrhagic infarction with multiple capillary thrombosis in an angiolipoma.

\section{Discussion}

The association of extensive haemangiomata and thrombocytopenia was described in 1940 (Kasabach and Merritt, 1940) and is now attributed to diffuse intravascular coagulation (Verstraete et al., 1965). A similar proliferation of capillaries is also found in angiolipomata, but no association with thrombocytopenia has previously been reported. In this case atrial fibrillation, gross heart failure and left bundle branch block suggested a recent myocardial infarction. In this condition platelet aggregation (Hampton and Mitchell, 1966), fibrinogen, and blood viscosity are frequently raised (Jan, Chien and Bigger, 1975) and increased incidence of deep vein thrombosis has been reported (Maurer, Wray and Shillingford, 1971). It is suggested that circulatory stasis whilst the patient was shocked, in conjunction with the presumed hypercoagulable state, led to diffuse clotting in the capillaries of the angiolipomata. This resulted in a sufficient amount of fibrinogen being consumed to cause a generalized clotting 
deficit; surprisingly, this was only clinically apparent in the skin overlying the angiolipomata, presumably secondary to extravasation from infarcted capillaries.

\section{Acknowledgment}

I thank Dr E. R. Beck for his assistance and permission to publish this case.

\section{References}

Hampton, J.R. \& Mitchell, M.R.A. (1966) Abnormalities of platelet behaviour in acute illness. British Medical Journal, 51, 1079
Jan, Kung-Ming, Chien, Shu \& Bigger, J.T., JR (1975) ָָ Observations on blood viscosity changes after myocardial infarction. Circulation, 51, 1079.

KaSABaCh, H.H. \& MerritT, K.K. (1940) Capillary heman-尺 gioma with extensive purpura. American Journal of $\subseteq$. Diseases of Children, 59, 1063.

MaURER, B.J., WRAY, R. \& ShILlingford, J.P. (1971) Frequency of venous thrombosis after myocardial infarction. Lancet, ii, 1385.

Verstraete, M., Vermylen, C., Vermylen, J. \& Vanden-互 BROUCKE, J. (1965) Excessive consumption of blood $\frac{\rho}{\sqrt{3}}$ coagulation components as a cause of hemorrhagic dia- $\mathbb{D}$ thesis. American Journal of Medicine, 38, 899.

\section{Fatal self-poisoning with Dettol}

\author{
DAVID MEEK \\ M.B., Ch.B.
}

ROGER GABRIEL M.Sc., M.B. M.R.C.P.
D. M. PIERCY

M.B., M.R.C.Path

\section{Departments of Medicine and Pathology, Royal Infirmary, Hull}

DETTOL is a common household disinfectant. A fatal case of self-poisoning with this agent is reported.

\section{Case history}

A 66-year-old housewife was admitted $90 \mathrm{~min}$ after ingesting, it was said, about $300 \mathrm{ml}$ of Dettol. She was unconscious with flaccid areflexic limbs but responded to deep and painful stimuli. The pupils were equal and constricted, responding sluggishly to light. The blood pressure was $90 / 0 \mathrm{mmHg}$, pulse 64 beats/min and respirations 18/min. The cardiovascular and respiratory systems were otherwise normal.

The initial plasma biochemistry showed a urea of $9.5 \mathrm{mmol} / \mathrm{l}$, sodium $136 \mathrm{mmol} / \mathrm{l}$, bicarbonate $9 \mathrm{mmol} / \mathrm{l}$, chloride $100 \mathrm{mmol} / \mathrm{l}$, SGOT $58 \mathrm{u} . / 1$ (normal range 8-22) and the SHBD $620 \mathrm{u} . / 1$ (normal range 90-190). A urine sample obtained by catheterization was of beetroot colour and contained blood, sugar and ketone bodies. Red blood cells were seen on microscopy. The urine sodium concentration was $70 \mathrm{mmol} / 1$.

Six and a half hours after taking the poison the conscious level lightened and the patient became cerebrally irritable with hypertonic limbs. The pupils were normal, equal in size and responded to

Correspondence: Dr Roger Gabriel, Renal Unit, St Mary's Hospital, London W2. light. The blood pressure had risen to $130 / 60 \mathrm{mmH}$ Two hours later she was fully conscious although drowsy. An irregular bradycardia of 50 beats $/ \mathrm{min}$ developed and the blood pressure fell to $100 / 0 \mathrm{mmHg}$.

The following morning $\left(21 \mathrm{hr}\right.$ after ingestion of $\frac{\mathbb{}}{\Phi}$ Dettol) the patient was confused but there was no $\overrightarrow{\vec{P}}$ evidence of any neurological deficit. Signs of pul- 은 monary oedema were present. An ECG showed a $\bar{T}$ sinus bradycardia. The blood urea was $13 \mathrm{mmol} / 1$ 类 and the plasma electrolytes normal. In order to exclude the possibility of poisoning from other 3 . sources, plasma and urine samples were examined $\dot{0}$ for a wide variety of drugs which are commonly encountered in overdose (Berry and Grove, 1973; $\delta$ Flanagan and Withers, 1972), but none was detected. ₹

Since catheterization, the patient had passed only $40 \mathrm{ml}$ of urine: haematuria, glycosuria and $\supset$ ketonuria were still present and the oliguria was unresponsive to intravenous frusemide. In view of $\bar{N}$ the oliguria, chest signs and rapidly rising blood 0 urea, peritoneal dialysis was commenced. Despite $\mathcal{O}$ a technically successful dialysis $37 \mathrm{hr}$ after taking the Dettol the patient deteriorated, with increasing 0 acidosis, tachypnoea, tachycardia and hypotension 0 and died within $1 \mathrm{hr}$.

\section{Post-mortem and histology findings}

Isolated areas of corrosive staining were present on the lips and chin, mouth, oesophagus, trachea 